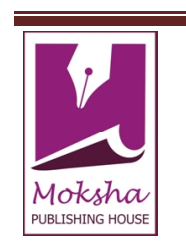

INTERNATIONAL RESEARCH JOURNAL OF PHARMACY

www.irjponline.com

ISSN $2230-8407$

Research Article

\title{
ANALYTICAL METHOD DEVELOPMENT AND VALIDATION FOR SIMULTANEOUS ESTIMATION OF SIMVASTATIN AND SITAGLIPTIN
}

Yaddanapudi Mrudula Devi*, R. Karthikeyan, Punttaguntla Sreenivasa Babu

Department of Pharmaceutical Analysis and Quality Assurance, Vignan Pharmacy College, Vadlamudi, Guntur, A.P, India

*Corresponding Author Email: mruduladeviy@gmail.com

Article Received on: 10/06/13 Revised on: 01/07/13 Approved for publication: 17/08/13

DOI: 10.7897/2230-8407.04836

IRJP is an official publication of Moksha Publishing House. Website: www.mokshaph.com

(C) All rights reserved.

\section{ABSTRACT}

A simple, specific, accurate, rapid, inexpensive isocratic Reversed Phase-High Performance Liquid Chromatography (RP-HPLC) method was developed and validated for the quantitative determination of Simvastatin and Sitagliptin pharmaceutical tablet dosage forms. RP-HPLC method was developed by using Inertsil ODS-3 C 18 (75 mm*4.6 mm) 5 microns Short column, Shimadzu LC-20AT Prominence Liquid Chromatograph. The mobile phase composed of 0.05 M Ammonium acetate: CAN 60:40. The flow rate was set to $1.0 \mathrm{~mL} \cdot \mathrm{min}^{-1}$ with the responses measured at $253 \mathrm{~nm}$ using Shimadzu SPD-20A Prominence UVVisible detector. Retention time of simvastatin and sitagliptin were found to be 3.260 and 2.136 minutes. Linearity was established for simvastatin and sitangliptin in the range of 25 to 150 and 10 to $60 \mu \mathrm{g} \cdot \mathrm{mL}^{-1}$ with correlation coefficient 1 . The validation of the developed method was carried out for specificity, linearity, precision, accuracy, robustness, limit of detection, limit of quantitation. The developed method can be used for routine quality control analysis of in simvastatin and sitangliptin pharmaceutical tablet dosage form.

Keywords: simvastatin and sitangliptin, Isocratic RP-HPLC, UV-Vis detector, Method Validation.

\section{INTRODUCTION}

Simvastatin (SIM), a methylated analog of lovastatin, is $-(+)-$ $\{1 S, 3 R, 7 S, 8 S, 8 a R)-1,2,3,7,8,8 a$-hexahydro-3,7-dimethyl-8[2-(2R,4R)-tetrahydro-4-hydroxy-6-oxo-2H-pyran-2-yl]naphthyl-2,2-dimethyl butanoate (Figure 1$)^{1}$. It acts by inhibiting HMG CoA reductase and is used for the treatment of hypercholesterolemia. After oral administration, this pro drug is converted into $\beta$ hydroxy acid of simvastatin, which is a potent inhibitor of $\mathrm{HMG}$ CoA reductase, a key enzyme required for the synthesis of cholesterol in liver.

The determination of Simvastatin has been carried out in tablets by UV-Spectrophotometry ${ }^{9,10}$, RP-HPLC ${ }^{11-16}$, HPTLC. A literature review reveals that no analytical method (neither UV spectrophotometric nor any other method) is available for the simultaneous estimation of Sitagliptin and Simvastatin in tablet dosage form in pharmaceutical preparations, which prompted to pursue the present work. The objective of the present work is to develop and validate new analytical methods for simultaneous determination of Sitagliptin and Simvastatin in tablet dosage form ${ }^{2-8}$. This communication forms the first report of a simple, sensitive and reproducible method for the simultaneous estimation of Sitagliptin and Simvastatin from combined dosage form. Sitagliptin (SIT), [(2R)-1-(2,4,5-trifluorophenyl)-4- oxo-4-[3-(trifluoromethyl)5,6 dihydro $[1,2,4]$ triazolo $[4,3-a]$ pyrazin-7 $(8 H)$-yl] butan-2amine $]^{1}$ is a well known hypoglycemic drug. STG is a novel oral hypoglycemic drug of the dipeptidyl peptidase 4 inhibitor class (Figure 2). Sitagliptin increased incretin levels (GLP-1 and GIP) which inhibit glucagon release, in turn decreases blood glucose, but more significantly increases insulin secretion. The determination of STG has been carried out in tablet by RP-HPLC by UV Spectrophotomerty ${ }^{9,10}$.

\section{MATERIALS AND METHODS}

\section{Instruments}

Quantitative HPLC was performed on a isocratic high performance liquid chromatograph (Waters Alliance 2695) with a LC-20AT VP pump, manual injector with loop volume of $20 \mu \mathrm{L}$ (Rheodyne), programmable variable wavelength
Shimadzu SPD-20A Prominence UV-Vis detector and Inertsil ODS $\mathrm{C}_{18}(75,4.6 \mathrm{~mm}, 5 \mu)$. The HPLC system was equipped with "Empower 2 software" software. In addition an electronic balance (sartorious bsa2245-cw), digital $\mathrm{pH}$ meter (micro processor model no- 1p-1395), a sonicator (biotechnics India (model no- 91250h mode), UV-Visible Spectrophotometer (Schimadzu) were used in this study.

\section{Standards and Chemicals Used}

Potassium dihydrogen orthophosphate (Analytical grade) and Ortho phosphoric acid (Analytical grade) from Merck Pharmaceuticals Private Ltd., Mumbai, India., while acetonitrile (HPLC grade) and triethylamine (HPLC grade) from Merck Pharmaceuticals Private Ltd., Mumbai, India. Sitagliptin and Simvastatin were procured from Merck Pharmaceuticals Private Ltd., Mumbai, India.

\section{Preparation of Mobile Phase}

$3.85 \mathrm{~g}$ of ammonium acetate was dissolved in $1000 \mathrm{ml}$ of milliQ water. The solution was adjusted to a $\mathrm{pH}$ of 4.0 with orthophosphoric acid. Then it was degassed in ultrasonicator and then filtered through $0.45 \mu$ pore size membrane filter. Mix a mixture of above buffer $600 \mathrm{ml}(60 \%)$ and $400 \mathrm{ml}$ of Acetonitrile HPLC (40 \%) and degas in ultrasonic water bath for 5 minutes. Filter through $0.45 \mu$ filter under vacuum filtration.

\section{Preparation of Calibration Standards}

Preparation of standard stock solution for Simvastatin

In the case of Simvastatin, $40 \mathrm{mg}$ of Simvastatin working standard was weighed accurately. They were transferred to $100 \mathrm{ml}$ volumetric flask dissolved and made up to the volume with mobile phase to obtain $400 \mu \mathrm{g} / \mathrm{ml}$ solution.

\section{Preparation of standard dilutions of Simvastatin}

From the stock solution, $2.5 \mathrm{ml}, 5 \mathrm{ml}, 7.5 \mathrm{ml}, 10 \mathrm{ml}, 12.5$ $\mathrm{ml}, 15 \mathrm{ml}$ were pipette out in to $100 \mathrm{ml}$ volumetric flask and made up to the mark with mobile phase to obtain dilutions 
with concentrations $10 \mu \mathrm{g} / \mathrm{ml}, 20 \mu \mathrm{g} / \mathrm{ml}, 30 \mu \mathrm{g} / \mathrm{ml}, 40 \mu \mathrm{g}$ / $\mathrm{ml}, 50 \mu \mathrm{g} / \mathrm{ml}, 60 \mu \mathrm{g} / \mathrm{ml}$ respectively.

Preparation of standard stock solution for Sitagliptin: In the case of Sitagliptin, $100 \mathrm{mg}$ of Simvastatin working standard was weighed accurately. They were transferred to $100 \mathrm{ml}$ volumetric flask dissolved and made up to the volume with mobile phase to obtain $1000 \mu \mathrm{g} / \mathrm{ml}$ solution.

\section{Preparation of standard dilutions of Sitagliptin}

From the stock solution, $2.5 \mathrm{ml}, 5 \mathrm{ml}, 7.5 \mathrm{ml}, 10 \mathrm{ml}, 12.5 \mathrm{ml}$, $15 \mathrm{ml}$ were pipette out in to $100 \mathrm{ml}$ volumetric flask and made up to the mark with mobile phase to obtain dilutions with concentrations $25 \mu \mathrm{g} / \mathrm{ml}, 50 \mu \mathrm{g} / \mathrm{ml}, 75 \mu \mathrm{g} / \mathrm{ml}, 100$ $\mu \mathrm{g} / \mathrm{ml}, 125 \mu \mathrm{g} / \mathrm{ml}, 150 \mu \mathrm{g} / \mathrm{ml}$ respectively.

\section{Procedure}

Inject each concentration in to the chromatographic system and measure the peak area. Plot the graph of peak area on y axis versus concentration on $\mathrm{x}$ axis. Calculate the correlation coefficient.

\section{Validation Study of Sitagliptin and Simvastatin}

An integral part of analytical method development is validation. Once the method has been developed, it is necessary to evaluate under the conditions expected for real samples before being used for a specific purpose. The method validation was performed as per ICH guidelines for the determination of Simvastatin and Sitagliptin in bulk and pharmaceutical dosage forms. The method was validated with respect to parameters including specificity, precision, accuracy, linearity, robustness, system suitability and limit of detection (LOD), limit of quantification (LOQ).

\section{Specificity}

The effect of wide range of excipients and other additives usually present in the formulations of Simvastatin and Sitagliptin in the determinations under optimum conditions is investigated. The specificity of the RP-HPLC method is established by injecting the mobile phase and placebo solution in triplicate and recording the chromatograms. The specificity results were presented in Table 4.

\section{Precision}

Precision of the method was performed as intraday and interday precision. To study the intraday precision, six replicate standard solutions of Simvastatin and Sitagliptin were injected. The percent relative standard deviation (\% RSD) was calculated. The acceptable criteria are not more than 2.0.

\section{Linearity}

Linearity graphs for the proposed assay methods were obtained over the concentration range of $25-150 \mu \mathrm{g} / \mathrm{ml}$ and $10-60 \mu \mathrm{g} / \mathrm{ml}$. Method of least square analysis was carried out for getting the slope, intercept and correlation coefficient values and results were presented in Table 2 . The linearity graphs of Simvastatin and Sitagliptin were shown in Figure 5 and 6.

\section{Accuracy (Recovery studies)}

The accuracy of the method was determined by calculating recovery of by the method of addition at three different levels $(80 \%, 100 \%$ and $120 \%)$. Percent recovery for Simvastatin and Sitagliptin by all the methods was found in the range of Table 7. The mean percentage recovery of Simvastatin and Sitagliptin at each level was $99.5 \%, 100.2 \%$ which were in the acceptance limit of 98 to $103 \%$ as shown in Table 6 .

\section{Robustness}

Robustness of the proposed methods was evaluated by making small changes in flowrate $( \pm 0.2 \mathrm{ml} / \mathrm{min})$, wavelength $( \pm 2 \mathrm{~nm})$ of the solution. The results were presented in Table 7.

\section{Ruggedness}

Ruggedness of the method was evaluated by comparing the results of assay of Simvastatin and Sitagliptin obtained from two analysts, system and two columns. RSD was always found to be $<2 \%$ which indicates the method was rugged.

\section{Limit of Detection (LOD)}

The limit of detection (LOD) is defined as the lowest concentration of the analyte that can be detected but not necessarily quantified. LOD is calculated using formula $(3.3 *$ S.D $)$ / Slope.

\section{Limit of Quantitation (LOQ)}

The limit of Quantitation (LOQ) is defined as the lowest concentrations of the analytes that can be qualified with acceptable precision and accuracy. LOQ is calculated using formula (10*S.D) / Slope.

\section{RESULTS AND DISCUSSIONS}

An effort has been made to identify a Simple, Precise, Specific and Accurate method for estimation of Sitagliptin and Simvastatin in formulation by using RP-HPLC method. During the selection of mobile phase several solvents were tried at various levels and finally selected mobile phase system was Acetonitrile: 0.05 M Ammonium Acetate Buffer of $\mathrm{pH} 4.0$ at ratio 40:60 at ambient temperature. The concentration of $(10 \mu \mathrm{g} / \mathrm{ml})$ of Sitagliptin and Simvastatin was prepared by using mobile phase. The above solution was scanned in the range of $200-400 \mathrm{~nm}$ by using UV-VIS spectrophotometer with mobile phase as reference. After considering all the system suitability parameters, Acetonitrile: $0.05 \mathrm{M}$ Ammonium Acetate Buffer (40:60) of $\mathrm{pH} 4.0$ was selected for analysis at optimized flow rate of 1.0 $\mathrm{ml} / \mathrm{min}$. The Retention time of SIT And SIM was found to be 2.1 minutes, 5 minutes respectively. The Linearity of SIT and SIM was carried out at different concentrations ranging from $25-150 \mu \mathrm{g} / \mathrm{ml}$ and $10-60 \mu \mathrm{g} / \mathrm{ml}$ and correlation coefficient was found to be 1 and 1 which indicates that the concentration had given good linearity. Accuracy was confirmed by Recovery Studies. The \% recovery of Sitagliptin and Simvastatin was found to be $99.5 \%, 100.2 \%$ which were in the acceptance limit of 98 to $103 \%$ as shown in Table 6. The Precision has done in two ways i.e., System Precision and Method Precision. The \% RSD values of Sitagliptin and Simvastatin for System Precision and Method Precision was found to be 0.35 and 0.23 and 0.32 and 0.44 respectively as shown in the Table 5 Which were in the acceptance limit of less than $2 \%$. The Specificity for these drugs was determined by using $0.1 \mathrm{~N} \mathrm{Hcl}, 0.1 \mathrm{~N} \mathrm{NaoH}$ for 60 minutes. When drug was mixed with $0.1 \mathrm{~N} \mathrm{Hcl}, 0.1 \mathrm{~N} \mathrm{NaOH}$ it was found to be occurrence of irregular peak and peak elution was not good. Above results has shown good Specificity. 
Yaddanapudi Mrudula Devi et al. Int. Res. J. Pharm. 2013, 4 (8)

Table 1: Optimized Chromatographic Conditions for Simultaneous Estimation of Simvastatin and Sitagliptin by RP HPLC

\begin{tabular}{|c|c|}
\hline \multicolumn{2}{|c|}{ Optimized Chromatographic Conditions } \\
\hline Mode of separation & Isocratic elution \\
\hline Mobile phase & $0.05 \mathrm{M}$ Ammonium Acetate: CAN $(60: 40)$ \\
\hline Column & Inertsil ODS $\mathrm{C}_{18}(75,4.6 \mathrm{~mm}, 5 \mu)$ \\
\hline Flow rate & $1 \mathrm{ml} / \mathrm{min}$ \\
\hline Detector wavelength & $253 \mathrm{~nm}$ \\
\hline Injection volume & $20 \mu \mathrm{l}$ \\
\hline Oven temperature & Ambient \\
\hline Run time & 12 minutes \\
\hline
\end{tabular}

Table 2: Linearity Results of SIM and SIT

\begin{tabular}{|c|c|c|c|}
\hline \multicolumn{2}{|c|}{ Sitagliptin } & \multicolumn{2}{c|}{ Simvastatin } \\
\hline Con. $(\boldsymbol{\mu g} / \mathbf{m l})$ & Area & Con. $(\boldsymbol{\mu g} / \mathbf{m l})$ & Area \\
\hline 25 & 440023 & 10 & 797145 \\
\hline 50 & 886133 & 20 & 1595582 \\
\hline 75 & 1312724 & 30 & 2400233 \\
\hline 100 & 1752182 & 40 & 3192209 \\
\hline 125 & 2188862 & 50 & 3978418 \\
\hline 150 & 2632535 & 60 & 4753369 \\
\hline Correlation Coefficient & 1 & Correlation Coefficient & 1 \\
\hline
\end{tabular}

Table 3: Assay Results of SIM and SIT

\begin{tabular}{|c|c|c|c|c|c|c|c|}
\hline Compound & Standard area & Sample area & Standard weight & Sample weight & Average weight & Label claim & Standard purity \\
\hline Simvastatin & 3148996 & 3154055 & $40 \mathrm{mg}$ & $301 \mathrm{mg}$ & $300 \mathrm{mg}$ & $40 \mathrm{mg}$ & $99.7 \%$ \\
\hline Sitagliptin & 1732920 & 1742406 & $100 \mathrm{mg}$ & $301 \mathrm{mg}$ & $300 \mathrm{mg}$ & $100 \mathrm{mg}$ & $99.75 \%$ \\
\hline
\end{tabular}

Table 4: Specificity Study

\begin{tabular}{|c|c|c|c|c|c|}
\hline & Sample Weight $\mathbf{( m g )}$ & Simvastatin Area & Sitagliptin Area & \% assay of Simvastatin & \% assay of Sitagliptin \\
\hline Acid degradation & 301 & 2819999 & 1521520 & $88.8 \%$ & $87.3 \%$ \\
\hline Base degradation & 301 & 2832183 & 1557970 & $89.18 \%$ \\
\hline
\end{tabular}

Table 5: Results of Precision Study

\begin{tabular}{|c|c|c|c|c|c|c|c|c|}
\hline \multirow[t]{2}{*}{ Injection samples } & \multicolumn{4}{|c|}{ System precision } & \multicolumn{4}{|c|}{ Method precision } \\
\hline & $\mathbf{R}_{\mathbf{t}}$ & Area & S.D & $\%$ RSD & $\mathbf{R}_{\mathbf{t}}$ & Area & S.D & $\%$ RSD \\
\hline \multirow[t]{6}{*}{ SIM } & 5.13 & 3206673 & \multirow[t]{6}{*}{7326.146} & \multirow[t]{6}{*}{0.23} & 5.081 & 3178938 & \multirow{6}{*}{$\begin{array}{c}14028 . \\
8\end{array}$} & \multirow[t]{6}{*}{0.44} \\
\hline & 5.11 & 3213605 & & & 5.077 & 3177020 & & \\
\hline & 5.10 & 3202295 & & & 5.071 & 3163649 & & \\
\hline & 5.09 & 3194559 & & & 5.066 & 3146634 & & \\
\hline & 5.08 & 3200967 & & & 5.062 & 3179110 & & \\
\hline & 5.09 & 3194557 & & & 5.057 & 3184166 & & \\
\hline \multirow[t]{6}{*}{ SIT } & 2.139 & 1761847 & \multirow[t]{6}{*}{6130.6} & \multirow[t]{6}{*}{0.35} & 2.132 & 1747035 & \multirow[t]{6}{*}{5645.9} & \multirow[t]{6}{*}{0.32} \\
\hline & 2.137 & 1762735 & & & 2.132 & 1741146 & & \\
\hline & 2.138 & 1768234 & & & 2.133 & 1757841 & & \\
\hline & 2.136 & 1753754 & & & 2.132 & 1747043 & & \\
\hline & 2.134 & 1753939 & & & 2.131 & 1744099 & & \\
\hline & 2.136 & 1753758 & & & 2.129 & 1747785 & & \\
\hline
\end{tabular}

Table 6: Recovery of SIM and SIT

\begin{tabular}{|l|c|c|c|c|c|c|}
\hline Inj. Sample & Spike level & area & Amount present & Amount recovered & \% recovered & Mean recovery \\
\hline \multirow{3}{*}{ Simvasatatin } & $50 \%$ & 4733579.3 & $50 \mathrm{mcg}$ & $50.11 \mathrm{mcg}$ & $100.22 \%$ & $100.28 \%$ \\
\cline { 2 - 7 } & $100 \%$ & 6360163.3 & $100 \mathrm{mcg}$ & $101.51 \mathrm{mcg}$ & $101.51 \%$ \\
\cline { 2 - 7 } & $150 \%$ & 7877120.6 & $150 \mathrm{mcg}$ & $148.70 \mathrm{mcg}$ & $99.13 \%$ & $99.95 \%$ \\
\hline \multirow{3}{*}{ Sitagliptin } & $50 \%$ & 2605649.3 & $50 \mathrm{mcg}$ & $49.57 \mathrm{mcg}$ & $99.41 \%$ & $99.65 \%$ \\
\cline { 2 - 7 } & $100 \%$ & 3493723.6 & $100 \mathrm{mcg}$ & $100.68 \mathrm{mcg}$ & $99.59 \%$ & \\
\cline { 2 - 7 } & $150 \%$ & 4322112.6 & $150 \mathrm{mcg}$ & $148.19 \mathrm{mcg}$ & \\
\hline
\end{tabular}

Table 7: Results of Robustness of SIM and SIT

\begin{tabular}{|c|c|c|c|c|c|c|c|c|}
\hline \multirow{2}{*}{$\begin{array}{c}\text { Parameter } \\
\text { Modifications }\end{array}$} & Plate count & Tailing & Rt & \multicolumn{2}{c|}{ Plate count } & Tailing & Rt \\
\cline { 2 - 8 } & \multicolumn{3}{c|}{ SIMVASTATIN } & \multicolumn{3}{c|}{ SITAGLIPTIN } \\
\hline Flow Rate (ml / min) & 0.8 & 6647 & 1.05 & 5.286 & 3622 & 1.32 & 2.2 \\
\cline { 2 - 8 } & 1.2 & 6684 & 1.02 & 5.155 & 3465 & 1.45 & 2.0 \\
\hline \multirow{2}{*}{$\begin{array}{c}\text { Mobile phase } \\
\text { Buffer: ACN }\end{array}$} & $50: 50$ & 6616 & 1.04 & 5.1 & 3564 & 1.25 & 2.5 \\
\cline { 2 - 8 } & $70: 30$ & 6654 & 1.07 & 5.2 & 3479 & 1.47 & 1.986 \\
\hline
\end{tabular}




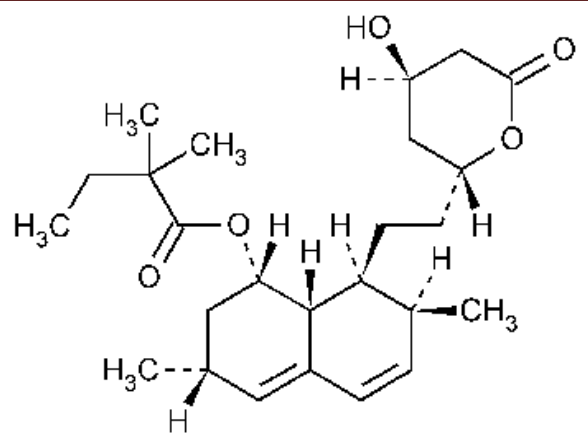

Figure 1: Structure of Simvastatin

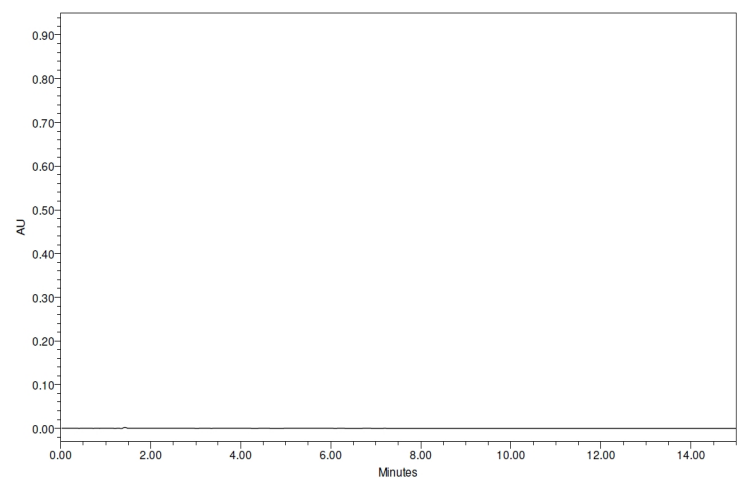

Figure 3: Chromatogram of Placebo<smiles>N[C@@H](CC(=O)N1CCn2c(nnc2C(F)(F)F)C1)Cc1cc(F)c(F)cc1F</smiles>

Figure 2: Structure of Sitagliptin

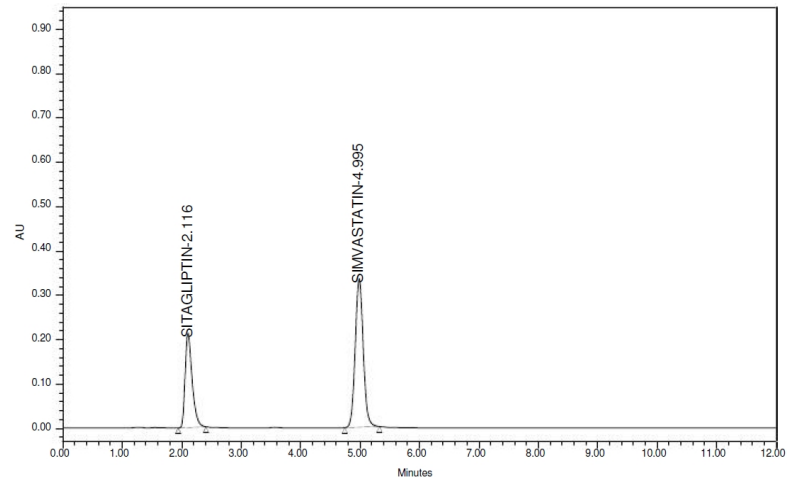

Figure 4: Chromatogram of SIT and SIM

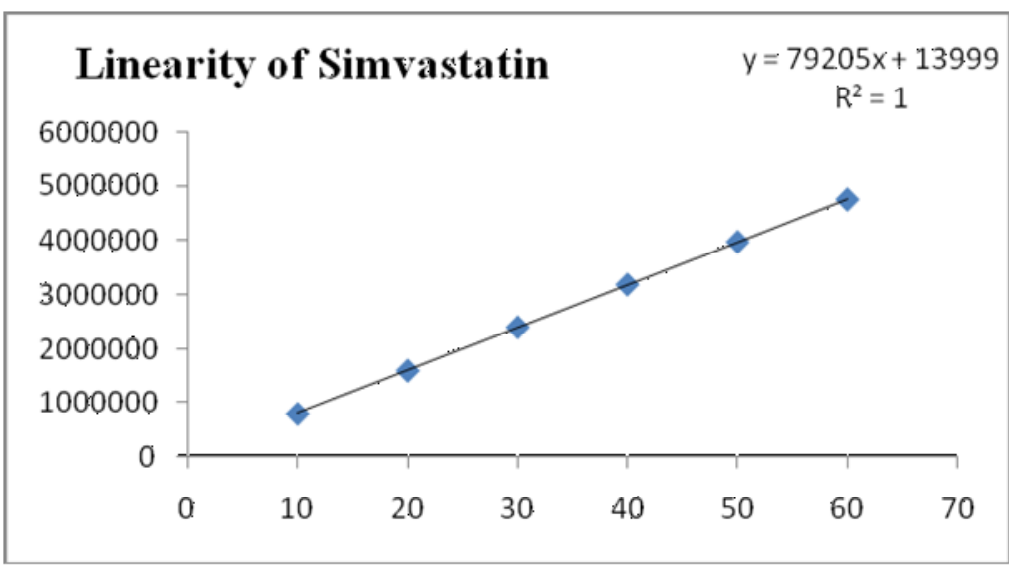

Figure 5: Linearity Curve of SIM

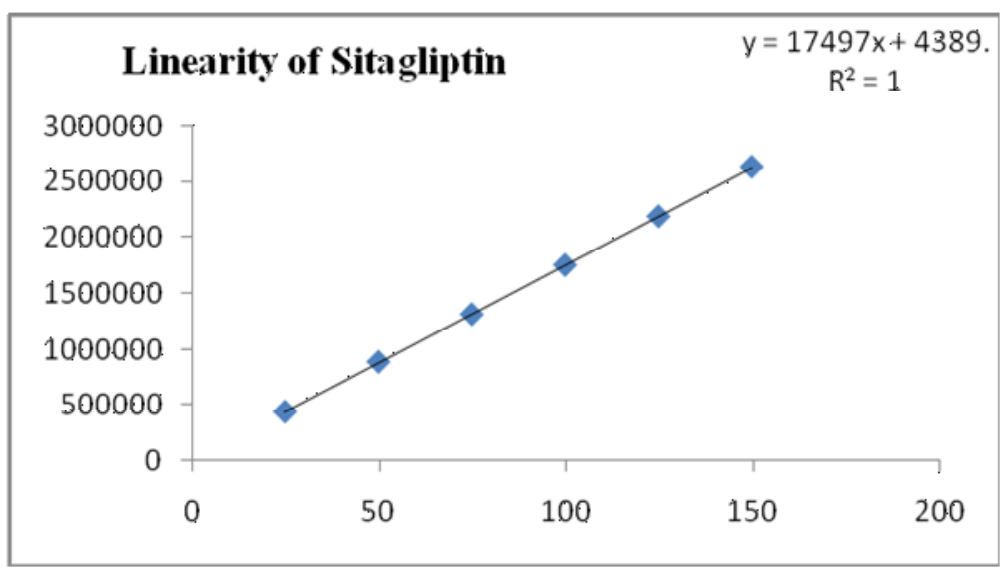

Figure 6: Linearity Curve of SIT 
The Robustness of the method developed was validated by changing the flow Rate and mobile phase has shown in Table 7. The selected flow rate and mobile phase gives good separation of drugs. The proposed method was analyzed by two different analysts by conducting Ruggedness. Hence the proposed method has good repeatability. The tablet formulation was selected for analysis. The nominal concentration (100\%) considered and $20 \mu \mathrm{l}$ of formulation was injected. The Assay percentage of SIT And SIM present in the sample was found to be $100.14 \%, 99.5 \%$ respectively. All the above parameters combined with the simplicity and ease of operation ensures that the RP-HPLC method can be applied for Simultaneous Estimation of Sitagliptin and Simvastatin in routine analysis of the two drugs in tablet dosage forms.

\section{CONCLUSION}

From the above experimental data and results, the developed HPLC method is having the following advantages:

- The standard and sample preparation requires less time.

- No tedious extraction procedure was involved in the analysis of formulation.

- Run time required for recording chromatograms were less than 10 minutes.

- Suitable for the analysis of raw materials, applicable to dissolution studies and can be used for the content uniformity studies.

Hence, the chromatographic method developed for the Simvastatin and Sitagliptin is said to be rapid, simple, specific, sensitive, precise, accurate and reliable that can be effectively applied for routine analysis in research institutions, quality control department in industries, approved testing laboratories.

\section{ACKNWOLEDGEMENT}

The authors thank to chairman Dr. L. Rathaiah, Vignan Pharmacy College for providing necessary facilities to carry out this research work.

\section{REFERENCES}

1. IUPAC Nomenclature for Chromatography IUPAC Recommendations, Pure and Appl. Chem 1993; 65(4): 819-872. http://dx.doi.org/10.1351/ pac199365040819

2. JW Munson. Pharmaceutical Analysis Modern Methods, International Medical Book Distributors, Part B; 2001. p. 17-20.

3. Willard HH, Merritt LL, Dean JA and Settle FA. Instrumental Methods of Analysis; CBS publishers and distributors, New Delhi, $7^{\text {th }}$ edition; 1986. p. 60-75.

4. Kenneth A. Text Book of Pharmaceutical Analysis, $3^{\text {rd }}$ edition, Jhon Willey; 1998. p. 373-379, 408.

5. Willard HH, Merritt LL, Dean JA and Settle FA. Instrumental Methods of Analysis; CBS publishers and distributors, New Delhi, $7^{\text {th }}$ edition; 1986. p. 650-651.

6. JW Munson. Pharmaceutical Analysis Modern Methods, International Medical Book Distributors, Part B; 2001. p. 17-20.

7. Rashmin. An Introduction to Analytical Method Development for Pharmaceutical Formulations. Directory of Open access Journal 2008; 6(4): 37-49.

8. Swarbrick James and Boylan James C. Encyclopedia of pharmaceutical technology, Marcel Dekker Inc. New York 1998; 1: 217-224.

9. Sharma Sheetal, Manocha Nimita, Bhandari Priya, Harsoliya Sohail and Jain Prabhat. Development of UV-SPectrophotometry and RP-HPLC Method and Its Validation for Simultaneous Estimation of Sitagliptin Phosphate and Simvastatin in Marketed Formulation. IJPBA 2012; 3(3): 673-678.

10. Kothari Ankur and Sheetal. Simultaneous UV Spectrophotometric Method for Estimation of Sitagliptin Phosphate and Simvastatin in Tablet dosage Form.JPR 2012; 5(1): 444-446.

11. Phaneemdra D, Venkatesh, Ramarao N. Simultaneous estimation of Simvastatin and Sitagliptin by using different analytical methods. IJAPA 2012; 2(1): 19-23

12. Lough WJ and Wainer IWW. HPLC Fundamental Principles and Practices, Blackie Academic and Professional; 1991. p. 52-67.

13. Gatti R, Lotti C. Development and validation of a pre-column reversed phase liquid chromatographic method with fluorescence detection for the determination of primary phenethylamines in dietary supplements and phytoextracts, Journal of Chromatography A 2011; 1218(28): 44684473. http://dx.doi.org/10.1016/j.chroma.2011.05.044 PMid:21652038

14. Ashutoshkar. Pharmaceutical Drug Analysis, $2^{\text {nd }}$ ed. New Age International Publishers; 2005. p. 466-467.

15. Sethi PD. HPLC Quantitative Analysis of Drug in Pharmaceutical Formulations; CBS publishers and distributors, $3^{\text {rd }}$ ed; 2001. p. 101-103.

16. Dixit RP, Barhate CR, Padhye SG, Viswanathan CL, MS Nagarsenker. Stability indicating RP-HPLC method for simultaneous estimation of Simvastatin and Ezetimibe from tablet dosage form, IJPS 2010; 72(2): 204-210.

Cite this article as:

Yaddanapudi Mrudula Devi, R. Karthikeyan, Punttaguntla Sreenivasa Babu. Analytical method development and validation for simultaneous estimation of simvastatin and sitagliptin. Int. Res. J. Pharm. 2013; 4(8):184-188 http://dx.doi.org/10.7897/2230-8407.04836 